\title{
Assessing Creativity of Senior High School Students in Learning Biology Using Online Portfolio Assessment on Facebook
}

\author{
Nengsih Juanengsih, Wulan Apriani, M Ahmad Danial \\ Syarif Hidayatullah State Islamic University Jakarta, J1. Ir. H. Djuanda 95, Ciputat, Indonesia \\ Corresponding e-mail: nengsih.juanengsih@uinjkt.ac.id
}

\begin{abstract}
Creativity is a meaningful ability and demands in improving the quality of education to produce creative learners. Assessment of creativity in the learning process is needed to contribute positively to the process and the achievement of learning outcomes in the development of creativity. This study aims to assess creativity of high school students using online portfolio assessment on the Facebook network in human motion system concept. This research was conducted at one of State Senior High School in Tangerang City. The research method used descriptive quantitative. The subjects of this study were 38 students of class XI Math \& Science. Instruments used are rubrics creativity and self-assessment sheets. We made a set of rubrics for assessing student creativity for poster and practicum report which uploaded on facebook. Creativity indicators consist of fluency, flexibility, originality, and elaboration. The result of the research shows that the creativity level of students is in a good category. We found student creativity in making poster is better than practicum report. we assumed this is because students have the freedom of expression in making posters rather than preparing more standardized practicum reports.
\end{abstract}

Keywords: creativity, online portfolio assessment, facebook,

\section{INTRODUCTION}

Many definitions of creativity have been put forward since then, but because creativity is complex and multifaceted in nature, there is no single, universally accepted. Treffinger in 1996 reviewed and presented more than 100 different definitions from the literature (Treffinger et al., 2002, p. 5). Plucker et al. (2004) cited in Kaufman, Plucker, \& Russell (2012, p. 61) creativity is the interaction among aptitude, process, and the environment by which an individual or group produces a perceptible product that is both novel and useful as defined within a social context. Runco \& Jaeger (2012, p. 92) state that the standard definition of creativity is bipartite: Creativity requires both originality and effectiveness. There are many different definitions in which the experts emphasize different elements or factors in creativity. It is also clear, that whatever aspect of creativity receives emphasis in any definition will have specific implications for how one seeks to assess that conception of creativity. (Treffinger et al., 2002, p. 8).
Treffinger et al. (2002, p 11) recognizing that creative behavior is influenced by motivational as well as situational factors, they clustered their final list of characteristics into four categories can be seen in Figure 1: generating ideas, digging deeper into ideas, openness and courage to explore ideas, and listening to one's "inner voice." the characteristics in the category generating ideas include fluency, flexibility, originality, elaboration, and metaphorical thinking.

Student creativity development is needed in the learning process that aims to equip the young generation in facing various problems and challenges of life in the future. The problem is that schooling often stops short of encouraging creativity; teachers and testers are often content if students have the knowledge. (Sternberg, 2012, p. 4)

A good learning process is to train the ability to think creatively so that learners become a creative person. The characteristic of a creative person is to have creative behavior resulting from creative thinking. The education system should be able to stimulate thinking, attitude, and productive-creative behavior, in addition to logical thinking and 
reasoning (Munandar, 1992, p. 47). The level of creativity will increase if the ability of creative thinking is often used and if not channeled, then the potential for creativity decreases. Although everyone has a creative talent if not nurtured, the talent will not develop, it can even become a hidden talent that cannot be realized (Munandar, 1992, p. 52).

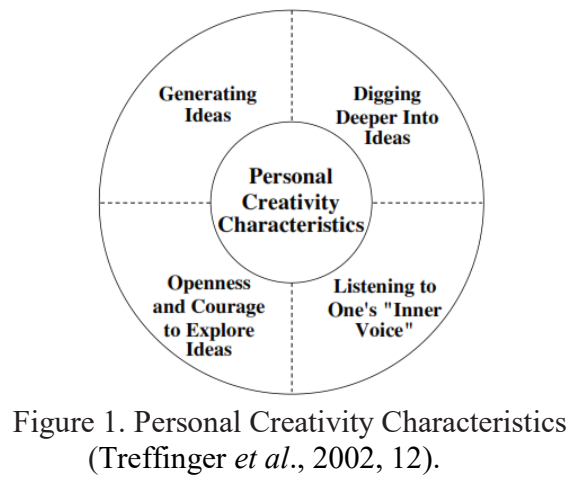

Barbot et al (2011, p. 125) stated that creativity involves a combination of cognitive (information processing), conative (personality traits, motivational aspects), and emotional factors (affective state, trait) that are interacting dynamically with the environment (which stimulates or inhibits the expression of creative potential) resulting in the uniqueness of the creative process and product. In terms of student creativity, teachers are responsible for carrying out assessments and providing feedback on student learning outcomes. Outcomes are the products and ideas that result from people's effort (Treffinger et al., 2002, p. 20).

Creativity assessment developed along with the evolution of the concept of creativity, and along with the questions that researchers addressed when developing their tools (Barbot, Besançon, \& Lubart, 2011, p. 125). One assessment tool that can be used to assess creativity is the portfolio (Lindström, 2007, p. 89). Portfolios can be used to view student progress over time based on a collection of works from learning activities. Portfolio assessment is one form of assessment that assesses students objectively, comprehensively, and accurately in accordance with the evidence they have.

Portfolio assessment requires a lot of time to access, is static data, and requires adequate storage, especially when the number of learners is large enough (Irawan, Astra, \& Bakri, 2012, p. 301). Utilization of technology as a medium in a portfolio can make a solution to apply it (Gibson \& Barrett, 2003, p. 559). That is a computer-based portfolio or e-portfolio or web-portfolio. What is an e-portfolio?
An e-portfolio is a digitized collection of artifacts, including demonstrations, resources, and accomplishment that represent an individual, group, community, organization, or institution. (Lorenzo \& Ittleson, 2005, p. 2). Several studies have shown that e-portfolio is effectively used as a tool for assessment (Pitts \& Ruggirello, 2012; Irawan, Astra, \& Bakri, 2012; Parkes, Dredger, \& Hicks, 2013, Bryant \& Chittum, 2013).

Mangkulo cited in Aisyah (2013, p. 3) reveals that implementing online learning, the school must provide the website for the learning process itself. Use of the website requires a fairly expensive cost and often teachers have difficulty in applying it. By considering the weakness of the website that has been described, in this study used social media Facebook as a substitute for the website. Based on previous research stated that Facebook can be used as an educational tool (Fewkes \& McCabe, 2012, 95; VanDoorn \& Eklund, 2013, p. 7; Miron \& Ravid, 2015, p. 371). Similar studies that have used facebook as a medium for online portfolio assessment are Khairunissa (2011) and Aisyah (2013, p.87).

Basic competence 3.5 in the biology learning system for class XI is to analyze the relationship between the structures of the organizing network so that it can explain the mechanism and disorder of the human motion system. Motion system concept is considered difficult in some students because it needs to understand the processes that take place in it and the relationship between the organs with each other. In this study will apply online portfolio assessment to assess the creativity of students in making the task of posters and practicum reports of disorder in the human motion system that is uploaded on facebook

\section{METHODS}

The research was conducted in one of state senior high school in Tangerang City, in October and November 2016. The research method used descriptive quantitative. The subjects of this study were 38 students of class XI Math \& Science, academic year 2016/2017. Instruments used are rubrics of creativity and self-assessment sheets. The rubric of creativity used to assess posters about disorder in human motion system (Table 1) and practicum report (Table 2). Self-assessment of students, to know the results of student evaluation in the form of advantages and disadvantages of his own work (Table 3). The self-assessment sheets were sent via messenger feature on a facebook in the form of yes or no questions. 
Table 1. Indicators in the rubric of creativity for Poster

\begin{tabular}{|c|c|c|}
\hline No. & $\begin{array}{c}\text { Component of } \\
\text { Creativity }\end{array}$ & Indicator \\
\hline 1. & Originality & $\begin{array}{l}\text { Students are able to create posters, the content of the poster produced is } \\
\text { different from that shown by the teacher and other students about the } \\
\text { motion system. }\end{array}$ \\
\hline 2. & Flexibility & $\begin{array}{l}\text { Students use } 3 \text { relevant references and according to the theme of human } \\
\text { motion system disorder. }\end{array}$ \\
\hline 3. & Fluency & $\begin{array}{l}\text { Students can inform the disorder of the human motion system through } \\
\text { images and writings in posters. }\end{array}$ \\
\hline 4. & Elaboration & $\begin{array}{l}\text { Students are able to present information according to the theme of motion } \\
\text { system disorder and provide appropriate colors to reinforce the } \\
\text { information in the poster. }\end{array}$ \\
\hline
\end{tabular}

Table 2. Indicators in the rubric of creativity for practicum report

\begin{tabular}{|c|c|c|c|}
\hline No. & $\begin{array}{r}\text { Component of } \\
\text { Practicum Report } \\
\end{array}$ & $\begin{array}{l}\text { Component of } \\
\text { Creativity }\end{array}$ & Indicator \\
\hline 1. & Aim & Fluency & $\begin{array}{l}\text { Determining ideas and ideas about the purpose of the practicum } \\
\text { performed. }\end{array}$ \\
\hline 2. & Basic Theory & Originality & $\begin{array}{l}\text { Presents concepts on a different theory basis from other } \\
\text { students. }\end{array}$ \\
\hline 3. & $\begin{array}{l}\text { Tools and } \\
\text { Materials }\end{array}$ & Flexibility & $\begin{array}{l}\text { Suggests an alternative use of tools and materials in a practicum } \\
\text { rarely found by other students. }\end{array}$ \\
\hline 4. & Work steps & Elaboration & $\begin{array}{l}\text { Revealed the work steps of practicum activities that have been } \\
\text { done smoothly }\end{array}$ \\
\hline 5. & Observation Result & Fluency & Revealed the observed data clearly. \\
\hline 6 & $\begin{array}{l}\text { Data Analysis and } \\
\text { Discussion }\end{array}$ & Fluency & $\begin{array}{l}\text { Analyze the observed data and write the discussion clearly and } \\
\text { fluently. }\end{array}$ \\
\hline 7 & Conclusion & Flexibility & Revealed the conclusion as an answer from the result of the lab \\
\hline
\end{tabular}

Table 3. Indicator in self-assessment sheets

\begin{tabular}{ll}
\hline No & \multicolumn{1}{c}{ Indicator } \\
\hline 1 & Preparation stage in poster creation \\
2 & Obtaining ideas in poster creation \\
3 & The things that make products attract \\
\hline
\end{tabular}

Data analysis is done quantitatively and through descriptive statistics. All subsequent data are integrated to be analyzed thoroughly for the preparation of conclusions about students' creativity assessment.

\section{RESULTS AND DISCUSSION}

In this research, students constructed four portfolios (four posters and four practicum reports) over the four weeks. The following will be presented the results of students' creativity in the form of the average of both tasks.

The students 'level of creativity assessment is done by analyzing the students' online portfolio tasks, ie making poster and practicum report. Both tasks are analyzed through student creativity rubrics by making percentages and categorizations based on categories of creative thinking. The categories were originality, flexibility, fluency, and elaboration.

Based on the results of the analysis, the level of students' creativity in created poster was a good category in each aspect. As shown in table 4. The example of the poster shown in Figure 2. Students' creativity in Practicum reports is quite varied. As shown in table 5 . The example of practicum report shown in Figure 3.

Fluency in created posters is evidenced by the relationship to each component in the poster. These components are symptoms, causes, prevention, and treatment as well as information that is easily understood. Information is conveyed through the form of images and writings so that posters are presented interactively and show the creativity of ideas owned by students.

Flexibility is the lowest indicator in created the poster. Generally, students use only one relevant reference and only a few use two relevant references in collecting information for the contents of the poster. Rubric creativity used by students can be said to have the ability to think flexibly if able to use three references to the contents poster. It is intended that the poster that is created contains accurate and reliable information. Nevertheless, the relevance of the poster theme to the content shows that students 
are still able to think flexibly so that this indicator is still good category.

Elaboration indicators or detailed thinking is seen from the effectiveness of the text content, and the suitability of colors contained in the poster to reinforce the information in it. On this indicator the average percentage of achievement of $69.73 \%$ with the high category. Most students are able to present brief but clear information and color the entire contents of the poster in accordance with one image to another to reinforce the information submitted.

Originality poster is a good category. The average percentage achievement of $63.81 \%$. New ideas that are generated include things that are difficult for everyone to do because they require different ways of thinking to create them but are essential in creativity. Based on the two types of online portfolio tasks analyzed, the task shows a better level of creativity than practicum reports. This is evidenced by the average level of creativity in created poster got percentage $67.43 \%$ while the preparation of practicum report $59.46 \%$.

The task of created posters and practicum reports is chosen because it is able to explain the level of creativity of writing in two different things, namely textual and visual. Practicum reports as a tool for measuring textual creativity, and posters as visual creativity tools. Aziz $(2012,65)$ has proven that learning creativity is more appropriate when integrated with writing skills. Writing activities will train students' creativity.

Table 4. Student creativity level in making poster disorder of human motion system

\begin{tabular}{cccc}
\hline No & $\begin{array}{c}\text { Component } \\
\text { of creativity }\end{array}$ & $\begin{array}{c}\text { Percentage } \\
(\%)\end{array}$ & Category \\
\hline 1 & Originality & 63.81 & Good \\
2 & Fluency & 73.68 & Good \\
3 & Flexibility & 62.50 & Good \\
4 & Elaboration & 69.73 & Good \\
\hline & Average & 67.43 & Good \\
\hline
\end{tabular}

When created poster, students are able to use their creativity in presenting new and unique information, effective content and color suitability so there is an interest to read it. Students combine various elements and display them in a different format from their friends. The highest creative thinking indicator that students achieve in created the poster was fluency with the percentage of $73.68 \%$. The lowest indicator was in the flexibility indicator with a percentage of $62.50 \%$. Both indicators are good categorized.

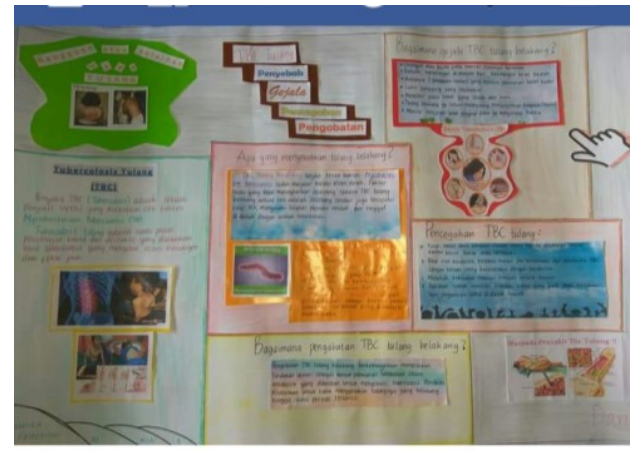

Q. Peronica Felentina $>$ BIOLOGI-MIA 3

Figure 2. Example Poster created by the student

Table 5. Student Creativity Levels in Practicum Report Tasks

\begin{tabular}{|c|c|c|c|}
\hline No & $\begin{array}{l}\text { Component of } \\
\text { creativity }\end{array}$ & $\begin{array}{c}\text { Percentage } \\
(\%)\end{array}$ & Category \\
\hline 1 & Originality & 30.92 & Very less \\
\hline 2 & Fluency & 53.29 & Sufficient \\
\hline 3 & Flexibility & 72.04 & Good \\
\hline 4 & Elaboration & 81.58 & $\begin{array}{l}\text { Very } \\
\text { Good }\end{array}$ \\
\hline & Average & 59.46 & Sufficient \\
\hline
\end{tabular}

Practicum report has a varying percentage on each indicator. The highest indicator of students' creative thinking is elaboration with a percentage of $81.58 \%$ (excellent). The lowest indicator is in originality indicator with the percentage of $30.92 \%$ (very less category).

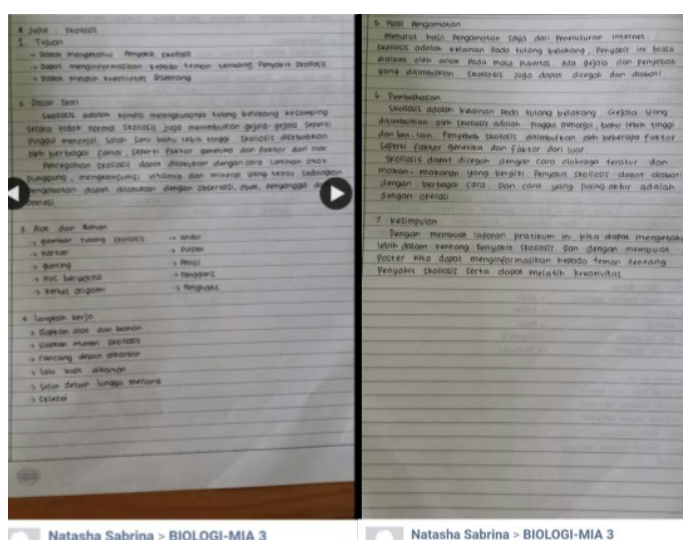

Figure 3. Example of a practicum report made by a student

The results that prove the difference in the level of students 'creativity in created poster and the practicum report also illustrate students' interest in both tasks. The level of creativity in practicum report 
is indeed lower, but using online portfolio can be one solution to create more compelling writing tasks through online media and allowing students to develop creativity.

Advantages of the online portfolio through Facebook not only can assess creativity but also can improve students' learning motivation. By the students uploading images to Facebook when they are at an attraction, more can be known about the learning process, and feedback can be offered throughout the process to guide them along the way, rather than provision of feedback only on the finished report (Backer, 2010, p. 24). Thus, simplifying the process and learning experience because in general learning is done conventionally. Students have pride in the task it produces and publishes it into Facebook. Other advantages train teachers and students to be responsible for the tasks in learning. Students are responsible for the tasks done and the teacher on the assessment as a fair and objective feedback without reducing the creativity of students.

\section{CONCLUSIONS}

Based on the results of research and data analysis has been done, it can be concluded that the level of creativity of students by using online portfolio assessment on Facebook was a good category. This can be seen from the results of the two tasks performed, the average percentage level of creativity of students in a created poster of $67.43 \%$ with a good category, and practicum reports of $59.46 \%$ with sufficient category.

\section{REFERENCES}

Aisyah, I . (2013). Pemanfaatan Jejaring Facebook Dalam Asesmen Portofolio Online Untuk Menilai Kreativitas Siswa SMP Pada Praktikum Penjernihan Air [Facebook Usage Utilization In Online Portfolio Assessment To Assess Creativity of Junior High School In Water Practice Practicum]. Unpublished Undergraduate Thesis. Department of Biology Education. Indonesia University of Education.

Azis, A. (2012). Menulis poster dan slogan melalui penerapan metode pembelajaran berbasis masalah (problem based learning) Suatu Alternatif Peningkatan Keterampilan Menulis [Writing posters and slogans through the application of problem-based learning methods An Alternative to Improving Writing Skills]. Jurnal Ilmiah Program Studi Pendidikan Bahasa dan Sastra Indonesia, 1(1), 65-74.
Backer, E. (2010). Using smartphones and Facebook in a major assessment: the student experience. $e$ Journal of Business Education \& Scholarship of Teaching, 4(1), 19-31.

Barbot, B., Besançon, M., \& Lubart, T.I. (2011). Assessing Creativity in the Classroom, The Open Education Journal, 2011, 4, 124-132. https://doi.org/10.2174/1874920801104010058

Bryant, L.H. \& Chittum, J.R. (2013). ePortfolio Effectiveness: A(n Ill-Fated) Search for Empirical Support. International Journal of ePortfolio, 3(2), 189-198.

Fewkes, A.M. \& McCabe, M. (2012). Facebook: Learning Tool or Distraction? Journal of Digital Learning in Teacher Education, 28(3), $92-$ 98.

Gibson, D. \& Barrett, H. (2003). Direction in electronic portfolio development. Contemporary Issues in Technology and Teacher Education, 2(4), 559-576.

Irawan, D., Astra, I.M., Bakri, F. (2012). Influence Of Implementation Online Portfolio Assessment Of Web-Based Learning Against The Students Learn Physics For High School Level. Jurnal Teknodik, XVI(3), 299-316.

Kaufman, J.C., Plucker, J.A., Russell, C.M. (2012). Identifying and Assessing Creativity as a Component of Giftedness. Journal of Psychoeducational Assessment, 30(1), 60-73. http://dx.doi.org/10.1177/0734282911428196

Khairunnisa. (2011). Pemanfaatan Jejaring Facebook Dalam Asesmen Portofolio Online Untuk Menilai Kemampuan Berpikir Kreatif Siswa SMA Pada Konsep Ekosistem [Facebook Usage Utilization In Online Portfolio Assessment To Assess Creative Thinking Ability High School Students At Ecosystem Concept]. Unpublished Undergraduate Thesis. Department of Biology Education. Indonesia University of Education.

Lindström, L .(2007). Understanding the Creative Mind: Portfolio Assessment in the Visual Arts, Proceeding of Linköping Electronic Conference, 89-94. Noorköping Sweden June 17-21, 2007, The 13th International Conference on Thinking.

Lorenzo, G., \& Ittleson, J. (2005). An overview of eportfolios. EDUCAUSE Learning Initiative, Paper $1 . \quad$ Retrieved from net.educause.edu/ir/library/pdf/eli3001.pdf

Miron, E., \& Ravid, G. (2015). Facebook Groups as an Academic Teaching Aid: Case Study and 
Recommendations for Educators. Educational Technology \& Society, 18 (4), 371-384.

Munandar, U. (1992). Mengembangkan Bakat dan Kreatifitas Anak Sekolah [Developing Talent and Creativity of School Children]. Jakarta: Grasindo.

Parkes, K.A., Dredger, K.S., Hicks, D. (2013). ePortfolio as a Measure of Reflective Practice International Journal of ePortfolio, 3(2), 99115.

Pitts, W \& Ruggirello, R. (2012). Using the ePortfolio to Document and Evaluate Growth in Reflective Practice: The Development and Application of a Conceptual Framework. International Journal of ePortfolio, 2(1), 49-74.

Runco, M.A., \& Jaeger, G.J. (2012). The Standard Definition of Creativity. Creativity Research Journal, 24(1), 92-96.

Sternberg, R.J. (2012). The Assessment of Creativity: An Investment-Based Approach. Creativity Research Journal, 24(1), 3-12.

Treffinger, D.J., Young, G.C., Selby, E.C., Shepardson, C. (2002). Assessing Creativity: A Guide for Educators. The National Research Center on The Gifted and Talented. Center for Creative Learning Sarasota, Florida.

VanDoorn, G., \& Eklund, A.A. (2013). Face to Facebook: Social media and the learning and teaching potential of symmetrical, sychronous communication. Journal of University Teaching \& Learning Practice, 10(1), 1-14. 